\section{The Anaerobic Compensation Point for Fresh-cut Watermelon and Implications for Postprocess Handling}

Jorge M. Fonseca ${ }^{1}$

Clemson University, Horticulture Department, Clemson, SC 29634-0375

James W. Rushing ${ }^{2}$

Clemson University, Coastal Research and Education Center, Charleston, SC 29414-5332

Robert F. Testin

Clemson University, Packaging Science Department, Clemson, SC 29634-0375

Additional index words. Citrulus lanatus, modified atmosphere, quality, minimally processed

Abstract. The influence of temperature and $\mathrm{O}_{2}$ concentration on respiration and shelf life of fresh-cut watermelon was investigated. Product stored at selected temperatures from 1 to $30{ }^{\circ} \mathrm{C}$ showed increasing respiration and reduced shelf life with increasing temperature. Oxygen depletion and $\mathrm{CO}_{2}$ evolution were measured using a closed system method and rates of $\mathrm{O}_{2}$ consumption and $\mathrm{CO}_{2}$ production were computed. A mathematical model found to predict the $\mathrm{CO}$, production as function of temperature and $\mathrm{O}$, showed an elevated rate of $\mathrm{CO}_{2}$ production at about $14 \% \mathrm{O}_{2}$ or lower. A modified atmosphere trial that compared product stored at 7 to $9{ }^{\circ} \mathrm{C}$ in air with product at either $14 \%$ or $8 \% \mathrm{O}_{2}$ revealed increased respiration in the latter treatments, suggesting a relatively high anaerobic compensation point $(\mathrm{ACP})$ at $>14 \% \mathrm{O}_{2}$. Our results suggest limited applicability of modified atmosphere packaging (MAP) for this product. Fresh-cut watermelon had extended shelf life and reduced respiration rate when stored at 1 to $3{ }^{\circ} \mathrm{C}$ and in $>14 \% \quad \mathrm{O}_{2}$ atmospheres.

The consumption of fresh-cut watermelon [Citrullus lanatus (Thunb. Matsum. and Nakai)] has increased at a rate of $20 \%$ to $30 \%$ annually, to the extent that $\approx 25 \%$ of all watermelon produced in U.S. is cut in some fashion for retail sale. Most of this processing is done in the supermarket due to the product's short shelf life (NWPB, 1998). Previously we determined that shock and vibration stress encountered during transportation is a major problem that must be addressed by regional processors. Packaging that diminishes cubeto-cube friction appeared to be a promising solution (Fonseca et al., 1999).

Refrigeration is the primary method for reducing the respiration rate and quality deterioration of fresh fruits and vegetables (Cameron et al., 1994; King and Bolin 1989). Intact watermelon stored below $10{ }^{\circ} \mathrm{C}$ may suffer chilling injury, which may be manifested as water-soaked areas in the pulp (Risse and Maynard 1990). The respiration rate of intact watermelon ranges between 10 and $20 \mathrm{~mL}$ $\mathrm{CO} \mathrm{kg}^{-1} \cdot \mathrm{h}^{-1}$ at $18{ }^{\circ} \mathrm{C}$ (Elkashif et al., 1989). Watada et al. (1996) and Gorny (1997) reviewed respiration rates and optimum temperatures for storage of fresh-cut products but their reports

Received for publication 13 Nov. 2002. Accepted for publication 25 June 2003. South Carolina Agricultural Experiment Station Technical Contribution No. 4872 . This work was partially supported by the South Carolina Agricultural Society, Charleston, SC the Wade Stackhouse Foundation, Clemson, SC and CONICIT-MICIT, Costa Rica.

${ }^{1}$ Current address: The University of Arizona-Yuma Agricultural Center, Yuma, AZ 85346.

${ }^{2}$ Corresponding author; emailjrshng@clemson.edu. or skin to restrict gas diffusion (Watada, 1999). However, there are several exceptions: orange slices, for example, undergo anaerobic respiration below 14\% $\mathrm{O}_{2}$ (Gorny, 1997), and sweetpotatoes may shift to anaerobic conditions at external oxygen concentrations below 7\% (Chang and Kays, 1981). Little has been reported addressing the effect of $\mathrm{O}_{2}$ and $\mathrm{CO}_{2}$ on fresh-cut watermelon physiology. Cartaxo et al. (1997) observed unsatisfactory quality of watermelon cubes stored in $3 \% \mathrm{O}_{2}$ atmospheres, but higher $\mathrm{O}_{2}$ concentrations were not tested in that study. Perkins-Veazie et al. (1998) measured respiration of watermelon slices (flesh and rind) stored in jars at $10{ }^{\circ} \mathrm{C}$, observing an increase in rate from storage day 1 to 5; these results, however, were not associated with any physiological or environmental factor.

Several models have been used to predict aerobic respiration of produce under closed systems. A linear model (Hayakawa et al., 1975) and an enzymatic model (Lee et al., 1991), both based on $\mathrm{O}_{2}$ concentration as an inhibitor of fermentative $\mathrm{CO}_{2}$ production, are noted. Another model uses the ATP concentration as an inhibitor of fermentative $\mathrm{CO}_{2}$ production (Peppelenbos et al., 1996). However, our interest was to find a model that could predict the $\mathrm{CO}_{2}$ production $\left(\mathrm{KCO}_{2}\right)$ as a function of two factors - temperature and $\mathrm{O}_{2}$. Such a model could be useful to define the ACP and thus predict the onset of anaerobic respiration in products stored at different temperatures.

The objective of this work was to determine the influence of temperature and oxygen on the respiration and shelf life of fresh-cut watermelon. We provide evidence for defining the anaerobic compensation point and discuss implications for postprocess handling.

\section{Materials and Methods}

Fruit source. Seeded 'Royal Sweet' watermelon was used for the gas sampling and storage temperature components of the study and seedless cultivar 5244 was used to test the effects of initial $\mathrm{O}_{2}$ concentrations. The fruit originated from Mexico and were procured from a local Ingles Supermarket in Clemson, S.C.

Processing protocol and storage temperatures. Intact watermelon fruit were dipped for $1 \mathrm{~min}$ in a $200 \mathrm{mg} \cdot \mathrm{L}^{-1}$ chlorine solution. The peel was removed with a sharp knife and pulp cubes $(\approx 2.5 \mathrm{~cm}$ each dimension) were cut.

Shelf life determination. Cubes $(250 \mathrm{~g})$ were placed into a polypropylene (PP) cupand-lid packages (340 g capacity, Fabri-Kal Corporation. Kalamazoo, Mich.), currently used commercially for fresh-cut watermelon. The packages were filled with air. To avoid contamination, the packages were previously irradiated with UV light $(250 \mathrm{~nm})$ for $3 \mathrm{~min}$ (420 $\mathrm{mJ} \cdot \mathrm{cm}^{-2}$ ) using a bulb-lamp (Germicidal lamp, American Ultraviolet Co., Beaufort, S.C.) placed $15 \mathrm{~cm}$ above the containers. The treatments consisted of experimental units of two packages of product with five replicates placed at six different storage temperatures: 1 , $3,7,11,15$, and $30^{\circ} \mathrm{C}$. Each day, the stored product was evaluated for color fading, dark- 
ening, off-odor, and overall visual quality by a group of 10 untrained panelists simulating typical retail customers. The quality of each watermelon cube was rated according to the following criteria: $10=$ excellent; $7=$ lowest point of salability; $5=$ definite consumer rejection point; and $0=$ extremely poor. The maximum shelf life of cubes in each container was defined as the period of time before the overall quality fell below level 7 according to its hedonic scale. Aerobic total count (ATC), using Petrifilm aerobic count plates (3M Co., St Paul, Minn.), was monitored on additional samples stored at temperatures $7^{\circ} \mathrm{C}$ and below, to estimate any effect of microbial population on quality judging and respiration results. A sample of $25 \mathrm{~g}$ of the product was prepared according to the film manufacturer's recommendations. Dilutions from $10^{1}$ to $10^{7}$ per $1 \mathrm{~g}$ of sample were incubated at $30{ }^{\circ} \mathrm{C}$ for $72 \mathrm{~h}$. Two cubes from each of three containers were sampled on the second, fifth and seventh day of the trial.

Respiration rate in a closed system. Watermelon cubes ( $200 \mathrm{~g}$ ) processed as previously described were placed into 480-mL glass jars with tight-fitting lids equipped with a rubber sampling port. The jars had been cleaned with $500 \mathrm{mg} \cdot \mathrm{L}^{-1}$ chlorine and irradiated with UV light as described. For each treatment, three fruit were used, each to fill five jars (replicates). The jars were stored at five different temperatures: $3,7,11,15$, and $30^{\circ} \mathrm{C}$. A closed system method was used for the measurement of $\mathrm{O}_{2}$ and $\mathrm{CO}_{2}$ concentration (Yam and Lee, 1995 . Zhu et al., 2001), with jars being sealed until the $\mathrm{CO}_{2}$ level reached above $20 \%$, as this was reported to be a safe level for fresh-cut watermelon (Cartaxo et al., 1997). At least twice per day, 1-mL samples were withdrawn from the headspace of each jar. Samples were analyzed for $\mathrm{O}_{2}$ and $\mathrm{CO}_{2}$ with a Tracor 540 capillary gas chromatograph fitted with a double column Altech CTR-1 and thermal conductivity detector. The first sample was taken within the first hour after cutting. Respiration rate, as $\mathrm{CO}_{2}$ production $\left(\mathrm{KCO}_{2}\right)$ in $\mathrm{mL} \cdot \mathrm{kg}^{-1} \cdot \mathrm{h}^{-1}$ at a given $\mathrm{O}_{2}$ level and $\mathrm{CO}_{2}$ level, was then calculated according to Kays (1991):

$\mathrm{KCO}_{2}=\left(\% \mathrm{CO}_{2} \times 10\right) \mathrm{V} /(\mathrm{W} \mathrm{t})$

where $\% \mathrm{CO}=$ change in carbon dioxide concentration $(\%), \mathrm{V}=$ free space volume of container $(\mathrm{L}), \mathrm{W}=$ product weight $(\mathrm{kg})$, and $\mathrm{t}$ $=$ time container was closed $(\mathrm{h})$. The trial was repeated $14 \mathrm{~d}$ later.

Respiration with different initial levels of oxygen. An experiment was conducted to compare the effects of different initial levels of $\mathrm{O}_{2}$ to further verify the interpretation of results of the preceding study. Watermelon cubes (100 g) processed as previously described were placed into $300-\mathrm{mL}$ pouches with zero permeability to gases during short-term storage. Four pouches, each with cubes from a different fruit, were used per treatment. For the reduced $\mathrm{O}_{2}$ treatments, the pouches were internally vacuumed and filled with the predetermined gas mix. The treatments consisted of 1) $14 \%$ $\mathrm{O}_{2}$ (balance $\mathrm{N}_{2}$ ), 2) $8 \% \mathrm{O}_{2}$ (balance $\mathrm{N}_{2}$ ), and 3) air. In addition, control pouches containing the gas mix but without product were maintained

throughout the study to monitor leakage of the to $9{ }^{\circ} \mathrm{C}$. Gases in the pouches were sampled at least daily and analyzed until headspace $\mathrm{O}_{2}$ was below $1 \%$ in treatments.

Statistical analysis. Statistical analysis to assess the effect of temperature on shelf life was computed by nonlinear regression procedures using the SAS 6.2 General Linear Model (SAS Institute, Cary, N.C.). ANOVA at $P \leq 0.05$ was used for determining differences in microbial population. The gas concentration against time data were plotted with MS-Excel 2000 (Microsoft Co., Seattle, Wash.) and SAS 6.2 response surface regression analysis was used to determine the mathematical function that best characterized respiration as function

\section{Results and Discussion}

Shelf life determination. The shelf life of fresh-cut watermelon decreased with increasing temperatures (Fig. 1). The cubes stored at 1 or $3{ }^{\circ} \mathrm{C}$ had significantly longer shelf life $(\approx 10 \mathrm{~d})$ than cubes stored at or above $7{ }^{\circ} \mathrm{C}$ ( $<6 \mathrm{~d})$. Moreover, the predicted data yielded by a nonlinear regression $\left(r^{2}=0.96\right)$ revealed a maximum inflection between 4 and $6{ }^{\circ} \mathrm{C}$, supporting the importance of storing this product below this range. Microbial population, which was monitored for temperatures 7 ${ }^{\circ} \mathrm{C}$ and below, increased from $\approx 3 \log _{10} \mathrm{CFU} / \mathrm{g}$ on the second day to near $6 \log _{10} \mathrm{CFU} / \mathrm{g}$ on the seventh day. The results comparing each temperature, however, were statistically non significant (data not shown). Within this temperature range, the microbial count did not appear to be affecting the judging of quality of the product. Quality parameters, including color fading and darkening, off-odor, and juice leakage also confirmed the benefits of storage at the lower temperatures (data not shown). In all cases, rejection of cubes was associated with unpleasant off-odor. Occurrence of random water-soaked cubes was observed in the 1 to $7^{\circ} \mathrm{C}$ range. In other studies, this had been associated with the section of the fruit from which cubes were cut (Fonseca, 2000).

Although the rigid plastic containers used pouches. The pouches were then stored at 7 of temperature and gas concentration.

in retail stores and in the previous experiments are not designed for MAP due to leakage, we observed in a separate study that the headspace oxygen in some filled containers did decrease to as low as $15.8 \% \mathrm{O}_{2}$ after $5 \mathrm{~d}$ of storage at $2.8^{\circ} \mathrm{C}$ (Fonseca, 2000). Due to variability in container leakage rates the internal atmospheric modification was not consistent and these containers were not considered to be suitable for MAP studies.

Respiration rate in a closed system. The temporal pattern of $\mathrm{CO}_{2}$ production of freshcut watermelon obtained using Eq. [1] was similar to those of other fresh-cut products such as broccoli florets (Rushing, 1990) and cut iceberg lettuce (Smyth et al., 1998). The rate was initially higher immediately after cutting, ranging between 25 to $50 \mathrm{~mL} \mathrm{CO}$ per $\mathrm{kg}^{-1} \cdot \mathrm{h}^{-1}$, an apparent result of wound metabolism, then dropping to a plateau of about one-eighth the initial level in $<10 \mathrm{~h}$ when stored at temperatures below $15^{\circ} \mathrm{C}$ (Fig. 2). The rate at this stable stage was higher at higher temperatures. An increase in $\mathrm{CO}_{2}$ evolution was observed at all temperatures after a period of time, but the delay in the increased $\mathrm{CO}_{2}$ was longer and the increased level was lower at lower temperatures.

Considerable variability was noted in respiration rate during the first $6 \mathrm{~h}$ after processing (Fig. 2). This likely was due to the stress caused by cutting the product (Smyth et al., 1998). The resulting respiration data had a quadratic shape. Thus, we fitted the respiration data initiating with the 6-h sample into the following quadratic model:

$\mathrm{KCO}_{2}=\mathrm{b}+\mathrm{m}_{1}\left(\mathrm{O}_{2}\right)+\mathrm{m}_{2}(\mathrm{~T})+\mathrm{m}_{3}\left(\mathrm{O}_{2}\right)^{2}+\mathrm{m}_{4}(\mathrm{~T})^{2}$ where $\mathrm{T}=$ temperature $\left({ }^{\circ} \mathrm{C}\right)$.

The data adequately fit the proposed quadratic model $\left(r^{2}=0.94\right)$. The constant $\mathrm{b}$ and the parameters $\mathrm{m}_{1}, \mathrm{~m}_{2}, \mathrm{~m}_{3}$ and $\mathrm{m}_{4}$ in the Eq. [2] were $\mathrm{KCO}_{2}=7.507-0.871\left(\mathrm{O}_{2}\right)-0.056(\mathrm{~T})$ $+0.026\left(\mathrm{O}_{2}\right)^{2}+0.028(\mathrm{~T})^{2}$.

Excluding data from the first $5 \mathrm{~h}$, the model allowed the prediction of $\mathrm{CO}$ production as function of $\mathrm{O}_{2}$ and temperature, indicating a distinct increase in respiration rate at a relatively high $\mathrm{O}_{2}$ concentration. The model predicted the minimal $\mathrm{KCO}_{2}$ at exactly $16.7 \% \mathrm{O}_{2}$ for all temperatures evaluated. The measured increase

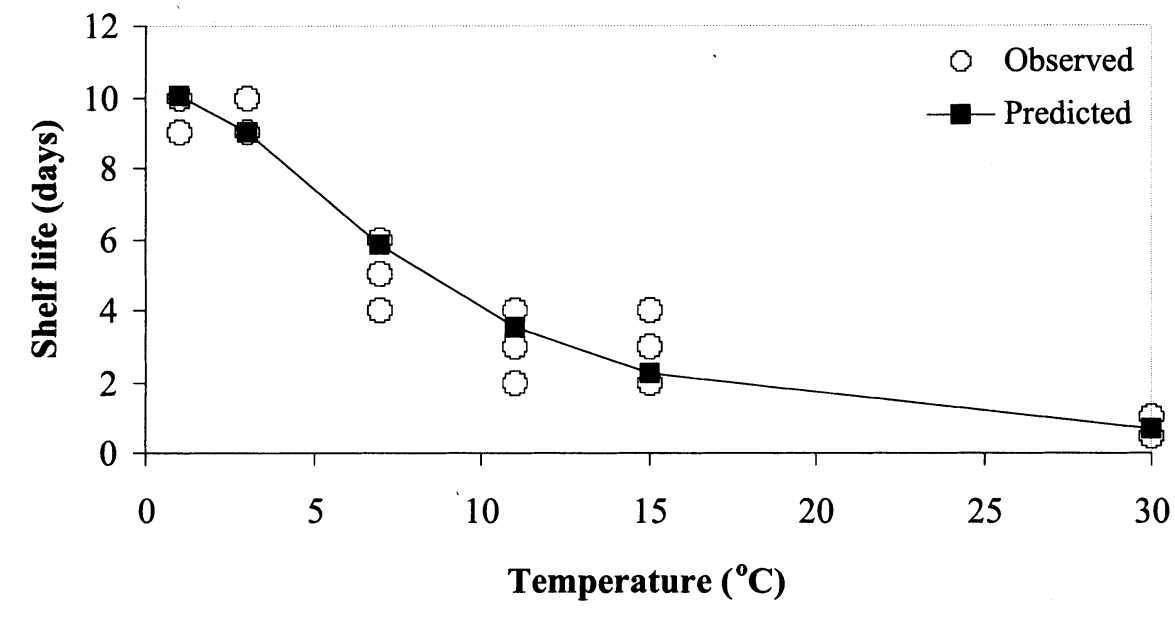

Fig. 1. Shelf life of fresh-cut watermelon as influenced by storage temperatures. Predicted data was estimated 
in respiration rate, however, was not substantial until $\approx 14 \%$ (Fig 3.). A similar ACP, which has been suggested as a minimum for the storage of orange slices at 0 to $5^{\circ} \mathrm{C}$, was accompanied by an increase in the evolution of ethanol and acetaldehyde (Gorny, 1997).

Respiration rate with different initial levels of Oxygen. The trial we conducted with different initial $\mathrm{O}_{2}$ levels in barrier pouches at 7 to $9^{\circ} \mathrm{C}$ revealed an increased $\mathrm{CO}_{2}$ production and $\mathrm{O}_{2}$ consumption for the treatments having
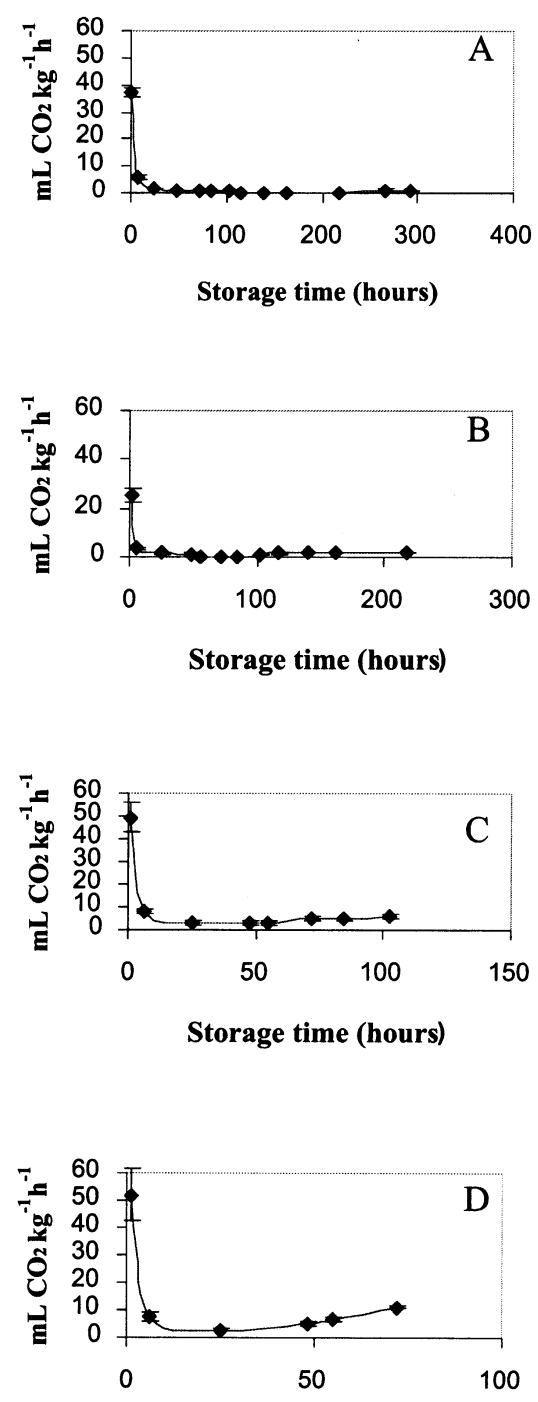

Storage time (hours)

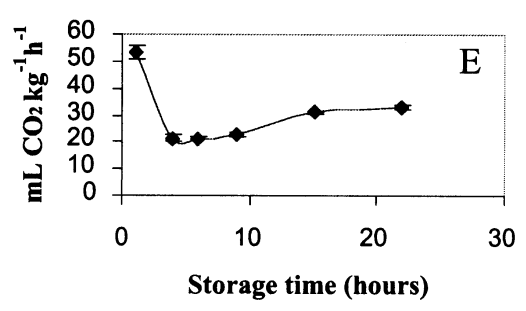

Fig. 2. Respiration rate of fresh-cut watermelon stored at five different air temperatures in a closed system: (A) 3, (B) 7, (C) 11, (D) 15, and (E) 30 \begin{tabular}{l}
${ }^{\circ} \mathrm{C}$. Vertical bars indicate \pm SE. When bars are \\
\hline
\end{tabular} absent the SE is smaller than the symbol. either $14 \%$ or $8 \%$ O (Fig 4). Although the air treatment had a higher respiration rate for the first sampling $(2 \mathrm{~h})$, this dropped to a stable level as was observed in previous experiments, maintaining a level of $1 / 3$ to $1 / 5$ the rate of the $\mathrm{O}_{2}$ modified treatments.

The $\mathrm{CO}_{2}$ accumulation in the pouches with air averaged $<2 \%$ after $12 \mathrm{~h}$, while pouches flushed with $8 \%$ or $14 \% \mathrm{O}_{2}$ accumulated $\approx 4 \% \mathrm{CO}$. This difference was maintained or increased for $74 \mathrm{~h}$, the point at which the $\mathrm{O}_{2}$ was depleted to $<1 \%$ for the reduced $\mathrm{O}_{2}$ treatments (Fig. 5). These results suggested a consistent tendency of the watermelon cubes to accelerate $\mathrm{CO}_{2}$ production at a relatively high $\mathrm{O}_{2}$ level, e.g., 14\%, verifying the hypothesis that $\mathrm{ACP}$ is above $14 \% \mathrm{O}_{2}$ suggested by the data from the prediction model. Several alcohols and aldehydes have been found as major volatile flavor and odor components in watermelons recently harvested (Kemp, 1975; Yahima et al., 1985). The concentration of these volatiles may change at a critical O level (Beaudry, 1999), which could partially explain the off-odor at the end of the shelf life of the product in the storage temperature trial.

When using data from the product in barrier pouches, the model approximated the respiration of the air treatment, but underestimated the $8 \%$ and $14 \%$ initial $\mathrm{O}_{2}$ level treatments when the $\mathrm{O}_{2}$ level was still above $1 \%$ (data not shown). This was expected as the model was based on data yielded from a closed system that had air at the starting point, and because increased $\mathrm{CO}$ may suppress respiration (Watkins, 2000). A study of increased $\mathrm{CO}_{2}$ with a nonmodified level of $\mathrm{O}_{2}$ may reveal whether such a treatment further extends shelf life of fresh-cut watermelon. Cartaxo et al. (1997) previously found positive results with high levels of $\mathrm{CO}_{2}$, which support this hypothesis.

The most important point with developing closed system models, as presented here, is to provide a pattern of respiration of a fresh-cut product at different temperatures and changing $\mathrm{O}_{2}$ or $\mathrm{CO}_{2}$ (if calculating respiration in terms of $\mathrm{O}_{2}$ consumption), and estimate the $\mathrm{ACP}$ level as described by Boersig et al. (1988). Accuracy should still be a concern, since our empirical model indicates a fixed lower $\mathrm{O}$ limit for the 0 to $30^{\circ} \mathrm{C}$ range. Beaudry et al. (1992) revealed that the RQB of blueberries increased with increasing temperature. The lower $\mathrm{O}_{2}$ limit also has been reported to increase with increasing temperature in whole apples (Gran and Beaudry, 1993), and raspberries (Joles et al., 1994). Despite this, Yearsley et al. (1997) reported ACP based on internal lower $\mathrm{O}_{2}$ limit and concluded that the effect of temperature on the ACP of whole apples stored between 0 and $28{ }^{\circ} \mathrm{C}$ was not significant. Little has been reported on the effect of temperature on the lower $\mathrm{O}_{2}$ limit of fresh-cut products but it appears that the effect is not as marked as with whole products, perhaps due to higher $\mathrm{O}_{2}$ diffusion in fresh cuts. Lakalul et al. (1999) observed an increase of the FT with increasing temperature in apple slices but the increase was only $0.2 \mathrm{kPa}$ in the range of 0 to $15^{\circ} \mathrm{C}$. Our regression estimated $94 \%$ of the respiration data and predicted a single ACP that was verified at 7 to $9{ }^{\circ} \mathrm{C}$. Experiments evaluating ACP at higher temperatures are needed to represent other temperatures also encountered during the retailing and consumer's handling.

Another consideration is that analyses were based on watermelon from a distant production region (Mexico). Transportation stress might have played a role in the observed ACP, as it has been reported that ACP shifts toward higher concentrations with the physiological aging of intact fruits (Boersig et al., 1988).

Since the model depends on changing gases, as in any closed or static system, a subsequent step must involve the use of permanent controlled atmospheres (Yang and Chinnan, 1988).

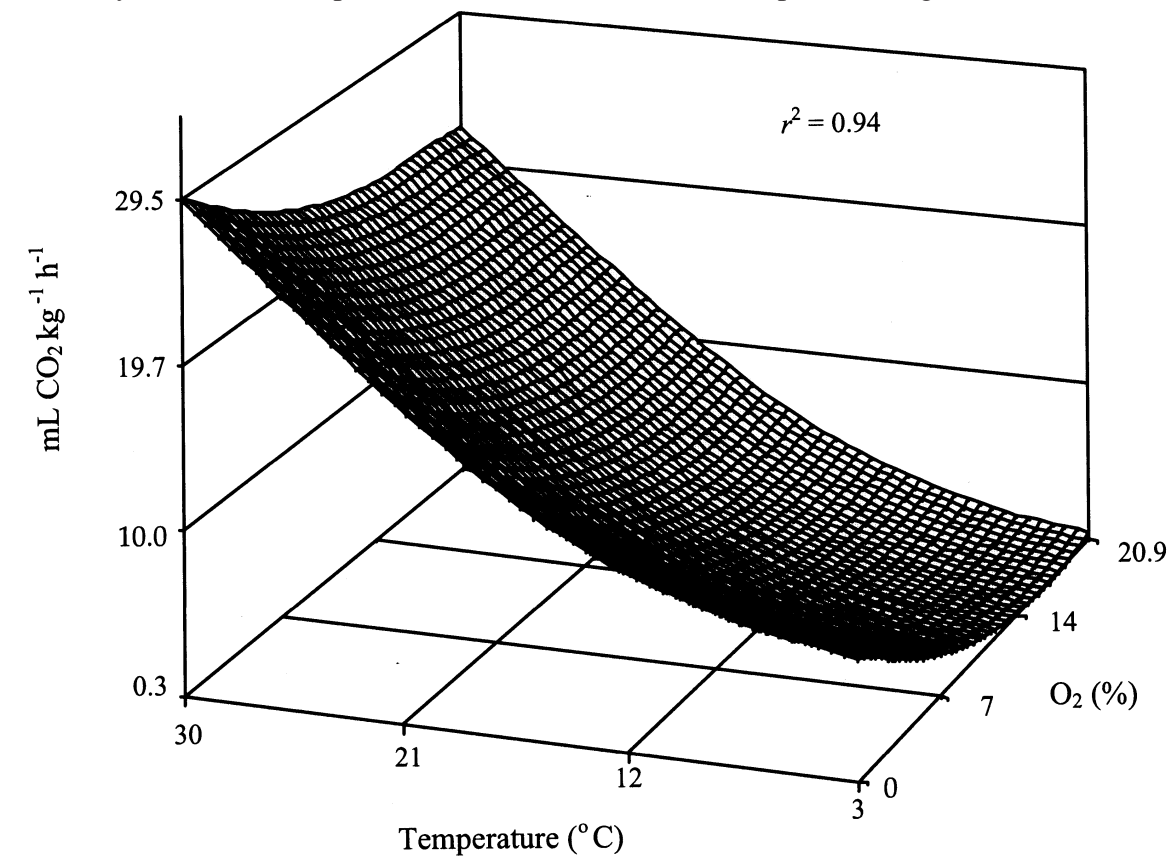

Fig. 3. Predicted plot surface of $\mathrm{CO}_{2}$ production of fresh cut watermelon as a function of $\mathrm{O}_{2}(\%)$ and temperature $\left({ }^{\circ} \mathrm{C}\right)$ based on data collected starting $6 \mathrm{~h}$ after storage. 


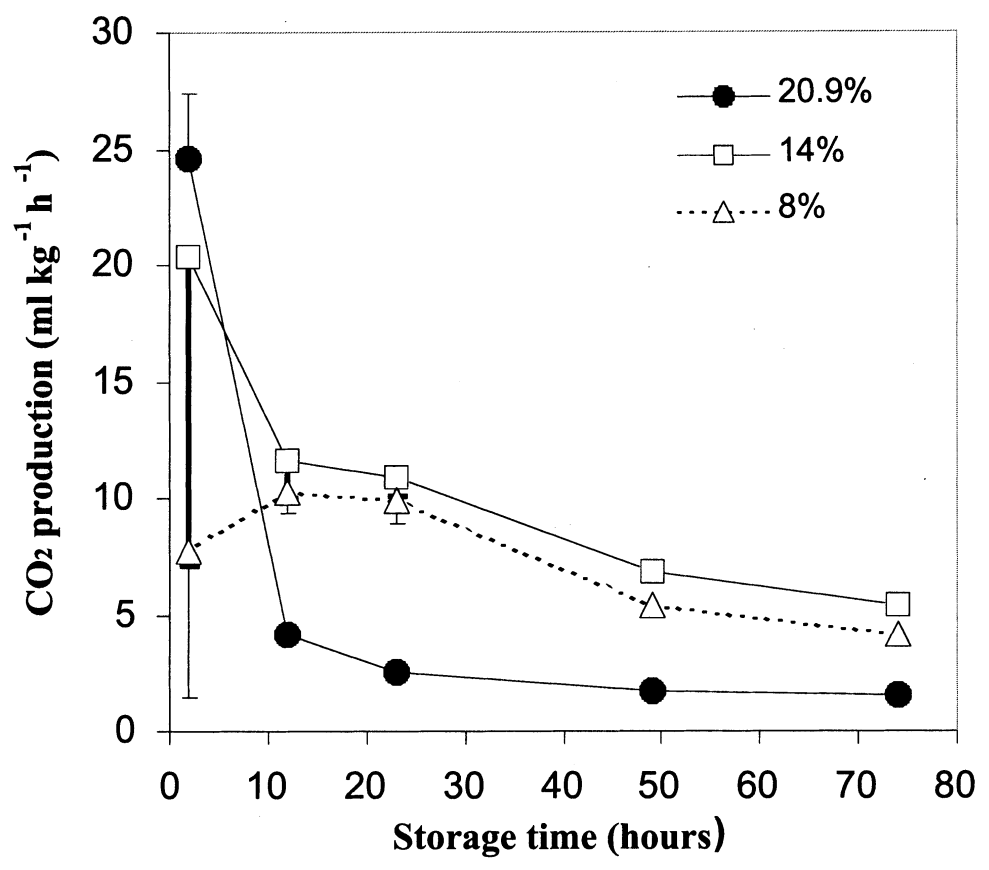

Fig. 4. Respiration rate of watermelon cubes stored in barrier pouches at 7 to $9{ }^{\circ} \mathrm{C}$ with initial $\mathrm{O}_{2}$ levels of $20.9 \%, 14.0 \%$, or $8.0 \%$. Vertical bars indicate \pm SE. When bars are absent the SE is smaller than the symbol.

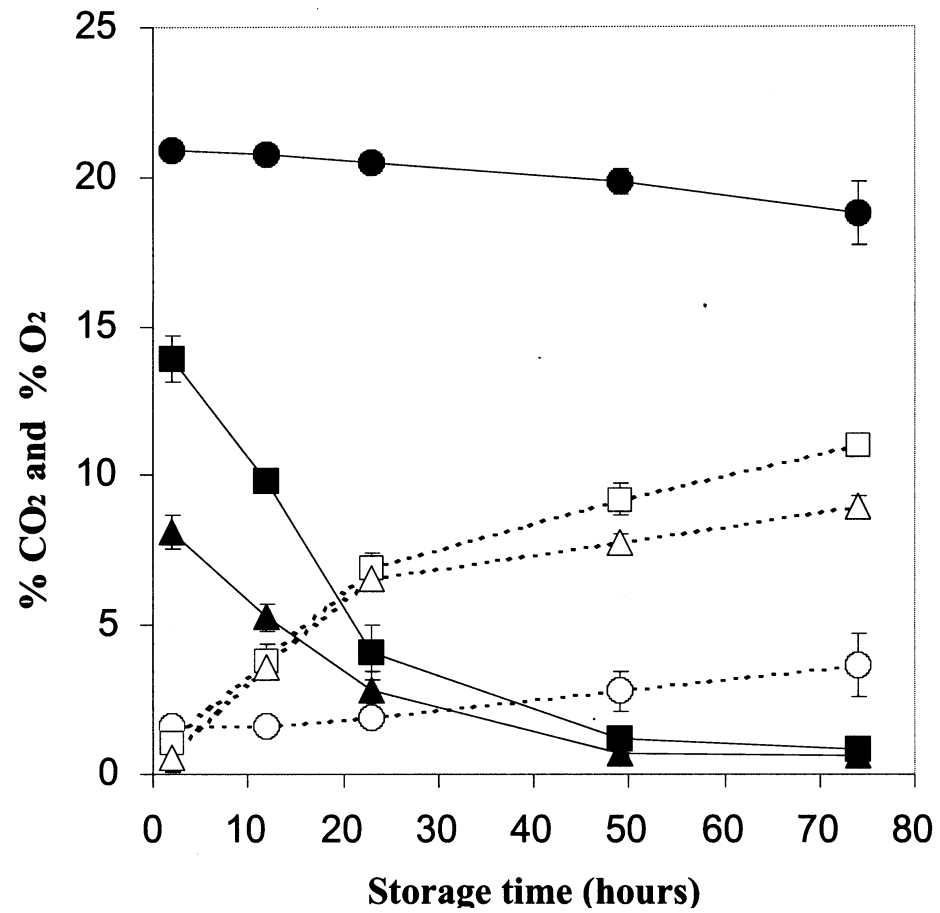

Fig. 5. Carbon dioxide and $\mathrm{O}_{2}$ levels in barrier pouches filled with watermelon cubes with different initial

$\mathrm{O}_{2}$ levels. Closed symbols $(\boldsymbol{\bullet}, \boldsymbol{\Delta}, \boldsymbol{\square})$ indicate $\mathrm{O}_{2}$ content in the headspace, while open symbols $(\mathrm{O}, \Delta$, 口) indicate $\mathrm{CO}_{2}$ content. Initial $\mathrm{O}_{2}$ levels in the packages were $20.9 \%(\boldsymbol{\bullet}, \mathrm{O}), 14 \%(\boldsymbol{\square}, \boldsymbol{\square})$, and $8 \%(\boldsymbol{\Delta}$

$\Delta)$. Vertical bars indicate \pm SE. When bars are absent the SE is smaller than the symbol.

The addition of $\mathrm{CO}_{2}$-salt forming bases such as $\mathrm{KOH}$ (Cameron et al., 1989) or the testing of different starting gas levels may also give additional insight. In this study, whether with an initial nonmodified atmosphere or with increased $\mathrm{CO}_{2}$ concentration in the headspace, the product respired more when exposed to an $\mathrm{O}_{2}$ level of $14 \%$ or lower than for air, suggesting limited applicability of MAP systems for extending the shelf life of this product. Our results should be useful for the design of

postprocessing handling protocols for fresh-cut watermelon, particularly in selecting storage temperatures and packaging materials.

\section{Literature Cited}

Beaudry, R.M. 1999. Effect of $\mathrm{O}_{2}$ and $\mathrm{CO}_{2}$ partial pressure on selected phenomena affecting fruit and vegetable quality. Postharvest Biol. Technol. 15:293-303.

Beaudry, R.M., A.C. Cameron, A. Shirazi, and D.L. Dostal-Lange. 1992. Modified atmosphere pack- aging of blueberry fruit: Effect of temperature on package $\mathrm{O}_{2}$ and $\mathrm{CO}_{2}$. J. Amer. Soc. Hort. Sci. 117:436-441

Boersig, M.R., A. A. Kader, and R.J. Romani. 1988. Aerobic-anaerobic respiratory transition in pear fruit and cultured pear fruit cells. J. Amer. Soc. Hort. Sci. 113:869-873.

Cameron, A.C., W. Boylan-Pett, and J. Lee. 1989. Design of modified atmosphere packaging system: Modeling oxygen concentrations within sealed packages of tomato fruits. J. Food Sci. 54:1413-1421.

Cameron, A.C., R.M. Beaudry, N.H. Banks, and M. V. Yelanich. 1994. Modified-atmosphere packaging of blueberry fruit: Modeling respiration and package oxygen partial pressures as a function of temperature. J. Amer. Soc. Hort. Sci. 119:534-539.

Cartaxo, C.B., S.A. Sargent and D.J. Huber. 1997. Controlled atmosphere storage suppresses mi crobial growth on fresh-cut watermelon. Proc. Fla. State Hort. Soc.110:252-257.

Chang, L.A and S.J. Kays 1981. Effect of low oxygen on sweet potato roots during storage. J. Amer. Soc. Hort. Sci. 106:481-483.

Elkashif, M., D.J. Huber, and J.K. Brecht. 1989. Respiration and ethylene production in harvested watermelon fruit: Evidence for nonclimacteric respiratory behaviour. J. Amer. Soc. Hort. Sci. 114:81-85.

Fonseca, J.M. 2000. Influence of processing and handling protocols on the physiology and shelf life of fresh-cut watermelon. MS thesis. Clemson Univ., Clemson, S.C.

Fonseca, J.M., J.W. Rushing, and R.F. Testin. 1999. Shock and vibration influence the shelf life of fresh-cut watermelon. Proc. Fla. State. Hort. Soc. 112:147-152.

Gorny, J.R 1997. A summary of CA and MA recommendations for selected fresh-cut fruits and vegetables, p. 30-66. In: Proc. $7^{\text {th }}$ Intl Controlled Atm. Res. Conf. vol. 5: Fresh-cut fruits and vegetables and MAP. Davis, Calif. 13-18 July 1997.

Gran, C.D., and R.M. Beaudry. 1993. Determination of the low oxygen limit for several commercial apple cultivars by respiratory quotient breakpoint. Postharvest Biol. Technol. 3:259-267.

Hayakawa, K.I., Y.S. Henig, and S.G. Gilbert. 1975 Formulae for predicting gas exchange of fresh produce packaged in polymeric films. J. Food Sci. 40:1033-1035.

Joles, D.W.,A.C.Cameron, A. Shirazi, P.D. Petracek, and R.M. Beaudry. 1994. Modified-atmosphere packaging of 'Heritage' red raspberry fruit: Respiratory response to reduced oxygen, enhanced carbon dioxide, and temperature. J. Amer. Soc. Hort. Sci. 119:540-545.

Kader, A.A., D. Zagory, and E. Kerbel. 1989. Modified atmosphere packaging of fruits an vegetables. CRC. Crit. Rev. Food. Sci. Nutr. 28:1-30.

Kays, S.J. 1991. Postharvest physiology of perishable plant products. $1^{\text {st }} \mathrm{ed}$. Van Nostrand Reinhold. New York.

Kemp, T.R. 1975. Identification of some volatile compounds from Citrullus vulgaris. Phytochemistry $14: 2637-2638$.

Knee, M. 1980. Physiological responses of apple fruits to oxygen concentrations. Ann. Appl. Biol. 96:243-253

King, A.D. and H.R. Bolin. 1989. Physiological and microbiological storage stability of minimally processed fruits and vegetable. Food Technol. 43(2):132-135,139

Lakalul, R., R.M. Beaudry, and R.J. Hernandez. 1999. Modeling respiration of apple slices in modified-atmosphere packages. J. Food Sci. 64:105-110. 
Lee, D.S., P.E. Haggar, J. Lee, and K.L. Yam. 1991 Model for fresh produce respiration in modified atmospheres based on principles of enzyme kinetics. J.Food Sci. 56:1580-1585.

National Watermelon Promotion Board. 1998. Watermelon's year-round availability boosting sales. Watermelon Market Rpt. 7(3):1-2

Peppelenbos, H.W. and R. Rabbinge. 1996. Respiratory characteristics and calculated ATP production of apple fruit in relation to tolerance of low $\mathrm{O}_{2}$ concentrations. J. Hort. Sci. 71:985-993.

Peppelenbos, H.W., L.M. Tijskens, J. Leven, and E.C. Wilkinson. 1996. Modelling oxidative and fermentative carbon dioxide production of fruits and vegetables. Postharvest Biol. Technol. 9:283-295.

Perkins-Veazie, P. J.K. Collins, and E. Baldwin. 1998. Shelf life of minimally processed watermelon. HortScience 33:605 (abstr.).

Platenius, H. 1942. Effect of temperature on the respiration rate and the respiration quotient of some vegetables. Plant Physiol. 17:179-197.

Risse, L.A. and D.N. Maynard. 1990. Evaluation of selected seedless watermelon cultivars during storage. Proc. Fla. State. Hort. Soc.
103:288-291.

Rushing, J.W. 1990. Cytokinins affect respiration, ethylene production, and chlorophyll retention of packaged broccoli florets. HortScience 25:88-90.

Smyth, A.B., J. Song, and A.C. Cameron. 1998. Modified atmosphere packaged cut iceberg lettuce: Effect of temperature and $\mathrm{O}_{2}$ partial pressure on respiration and quality. J. Agr. Food. Chem. 46:4556-4562.

Talasila P.C., K.V. Chau, and J.K. Brecht. 1992. Effects of gas concentrations and temperature on $\mathrm{O}_{2}$ consumption of strawberries. Trans. Amer. Soc. Agr. Eng. 35:221-224.

Watada, A.E., N.P. Ko, and D.A. Minott. 1996. Factors affecting quality of fresh-cut horticultural products. Postharvest Biol. Technol. 9:115-125.

Watada, A.E. 1999. Quality of fresh cut produce. Postharvest Biol. Technol. 15:201-205.

Watkins, C.B. 2000. Responses of horticultural commodities to high carbon dioxide as related to modified atmosphere packaging. HortTechnology 10:501-506.

Yahima, I., H. Sakakibara, J. Ide, T. Yanai, and
K. Hayashi. 1985. Volatile flavor components of watermelon (Citrullus vulgaris). Agr. Biol. Chem. 49:3145-3150

Yam, K.L. and D.S. Lee. 1995. Design of modified atmosphere packaging for fresh produce, p. 55-73. In: M.L. Rooney (ed.). Active food packaging. Blackie Academic and Professional, Imprint of Chapman and Hall, N.Z.

Yang, C.C. and M.S. Chinnan. 1988. Modeling the effect of $\mathrm{O}_{2}$ and $\mathrm{CO}_{2}$ on respiration and quality of stored tomatoes. Trans Amer. Soc. Agr. Eng. 31:920-925.

Yearsley, C. W., N.H. Banks, S. Ganesh, and D.J. Cleland. 1996. Determination of lower oxygen limits for apple fruit. Postharvest Biol. Technol. 8:95-109.

Yearsley, C.W., N.H. Banks, and S. Ganesh. 1997. Temperature effects of the internal lower oxygen limits of apple fruit. Postharvest Biol. Technol. 11:73-83.

Zhu, M., C.L. Chu, S.L. Wang, and R.W. Lencki. 2001. Influence of oxygen, carbon dioxide, and degree of cutting on the respiration rate of rutabaga. J. Food Chem. 66:30-37. 